\title{
Should university students be vaccinated against meningococcal disease in Canada?
}

\author{
Philippe De Wals MD PhD
}

\begin{abstract}
P De Wals. Should university students be vaccinated against meningococcal disease in Canada? Can J Infect Dis 2004;15(1):25-28.
\end{abstract}

OBJECTIVE: To evaluate the benefit and costs of vaccination of university students against invasive meningococcal disease (IMD) in Canada.

METHODS: Published studies were reviewed and a simulation model was used.

RESULTS: IMD risk seems to be of low magnitude, but consequences can be dramatic. Over a 10-year period, IMD risk reduction would be slightly greater using a monovalent $\mathrm{C}$ conjugate vaccine than a quadrivalent polysaccharide vaccine. From a societal perspective, costs per quality-adjusted life-years gained would be between $\$ 135,000$ and $\$ 698,000$, according to epidemiological scenarios and with vaccine purchase prices between $\$ 35$ and $\$ 50$ per dose.

CONCLUSIONS: Economic indices exceed proposed criteria for cost effective public health programs, but from the perspective of students and parents, the cost of vaccination might be worth the benefit.

Key Words: Cost benefit; Meningococcal disease; University; Vaccination

\section{Les étudiants universitaires devraient-ils se faire vacciner contre la maladie à méningo- coque au Canada?}

OBJECTIF : Évaluer le bénéfice et les coûts de la vaccination des étudiants universitaires contre la maladie à méningocoque envahissante (MME) au Canada.

MÉTHODOLOGIE : Des études publiées ont été analysées, et un modèle de simulation a été examiné.

RÉSULTATS : Le risque de MME semble faible, mais les conséquences peuvent être dramatiques. Sur une période de dix ans, la réduction du risque de MME serait légèrement plus élevée au moyen du vaccin monovalent conjugué de groupe $\mathrm{C}$ qu'au moyen du vaccin polysaccharidique quadrivalent. D'un point de vue sociétal, les coûts par années-personnes sans invalidité gagnées se situeraient entre 135000 \$ et 698000 \$ selon les scénarios épidémiologiques, tandis que le prix d'achat des vaccins oscille entre 35 \$ et $50 \$$ par dose.

CONCLUSIONS : Les indices économiques sont supérieurs aux critères proposés pour garantir des programmes de santé publique rentables, mais d'après la perspective des étudiants et des parents, le coût de la vaccination pourrait être justifié par le bénéfice.
Tn the United States, invasive meningococcal disease (IMD) in university students has been the subject of intense debate $(1,2)$. In 2000, the Advisory Committee on Immunization Practices issued a recommendation for health care providers to inform incoming first year university students and their parents about the risk of IMD and the availability of a safe and effective vaccine (3). In Canada, the National Advisory Committee on Immunization recognized that there are no data to suggest an increased IMD risk among students living in residence accommodation, but considered vaccination as an appropriate measure (4). The aim of this article is to review evidence on the risk of IMD in university students, and to evaluate the benefit and costs of vaccination from both societal and individual perspectives in Canada, using either the meningococcal quadrivalent ( $\mathrm{A}, \mathrm{C}, \mathrm{Y}$ and $\mathrm{W}-135)$ polysaccharide vaccine (Men-4-PS) or the meningococcal monovalent $\mathrm{C}$ conjugate vaccine (Men-C-Con).

\section{RISK OF MENINGOCOCCAL INFECTION}

For any individual, IMD risk is associated with the probability of exposure to a virulent strain of Neisseria meningitidis, and exposure is determined by the frequency, duration and closeness of interpersonal contacts, and by the prevalence of asymptomatic carriers among contacts (5). Bringing together groups of young adults in a university setting is a recipe for the transmission of meningococci. In a longitudinal study of asymptomatic carriage of meningococci among students in their first year at the University of Nottingham in the United Kingdom, the prevalence rate increased from $6.9 \%$ on day 1 to $23.1 \%$ on day 4 in the first week of term in October, and was up to $34.2 \%$ in some groups in December (6). Independent risk factors for acquisition were frequency of visits to bar halls, active smoking, visits to night clubs and intimate kissing.

Department of Social and Preventive Medicine, Laval University and National Institute of Public Health, Quebec City, Quebec.

Correspondence and reprints: Dr Philippe De Wals, Département de médecine sociale et préventive, Université Laval, Pavillon de l'Est, Local

1110, 2180, Chemin Sainte-Foy, Quebec G1K 7P4. Telephone 418-656-2131 ext 7374, fax 418-656-7759,

e-mail Philippe.Dewals@msp.ulaval.ca

Received for publication June 02, 2003. Accepted November 28, 2003 


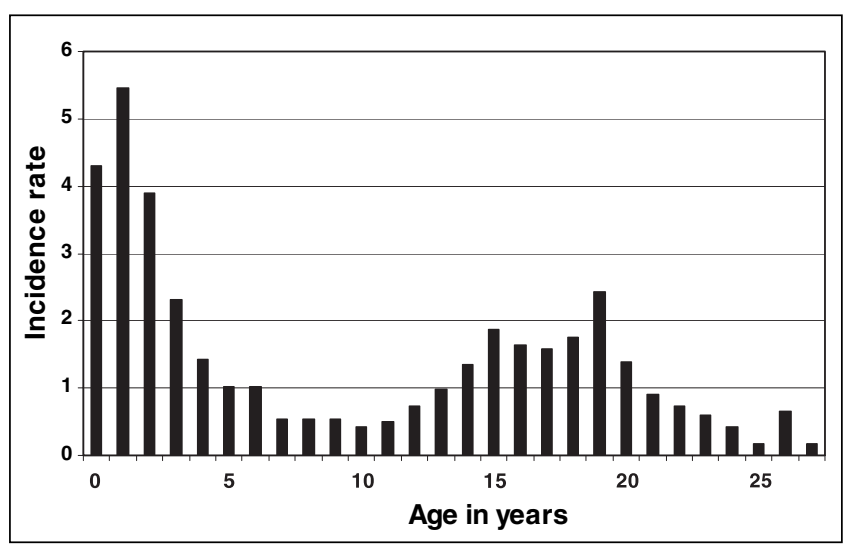

Figure 1) Incidence rate (per 100,000 per year) of invasive meningococcal disease in Canada, * according to age, from 1995 to 1998. Data from Health Canada, written communication

\section{RISK OF INVASIVE MENINGOCOCCAL DISEASE} In the literature, there have been reports of localized outbreaks in colleges and universities, and these were mainly caused by serogroup C strains (7-11). In the United Kingdom, an epidemiological study was performed during the period from 1994 to 1997 , and showed that university students had a 2.4-fold increased IMD risk compared with nonstudents of similar age in the same region (12). In the United States, during the 1998 to 1999 period, surveillance data indicated that undergraduate students had a 0.5 lower IMD risk compared with 18- to 23year old nonstudents (13). In first year students, however, IMD risk was 1.4-fold higher than that in the general population.

In Canada, there has been no study aimed specifically at assessing IMD risk among university students, and information on university attendance is not routinely collected in surveillance systems. During an interepidemic period, such as from 1995 to 1998, IMD incidence was slightly higher in individuals aged 19 years, compared with older and younger age categories, and this may well represent an increased incidence in first year university students (Figure 1). In the 18 to 27 years age group, serogroup $\mathrm{C}$ caused $55 \%$ of IMD cases of known serogroup, serogroup B caused $35 \%$ of cases and serogroups A, W-135 and Y represented 10\% of cases altogether. In Quebec, university usually begins at 19 years of age, and during the large serogroup C outbreak, in 1990 to 1992, IMD incidence was also slightly higher at age 20 years, than in older age categories (Figure 2). During more recent serogroup $\mathrm{C}$ outbreaks in Alberta (14) and in British Columbia (15), university students were not recognized as a high risk category. In Quebec in 2001, serogroup C IMD clusters occurred in secondary schools, but not in universities (16).

Behavioural factors associated with an increased IMD risk among university students were similar to those found for asymptomatic carriage and included residence on campus, residence in dormitories, visiting/spending time in cafeterias and bars, alcohol consumption, active and passive smoking, and French kissing $(12,17)$. It is, however, difficult to disentangle the independent effects of these highly correlated variables. IMD in young adults is particularly severe. In a review of IMD cases among college students in Allegheny county in Pennsylvania, the case fatality rate was $11 \%$, and $20 \%$ of survivors had permanent physical sequelae (18).

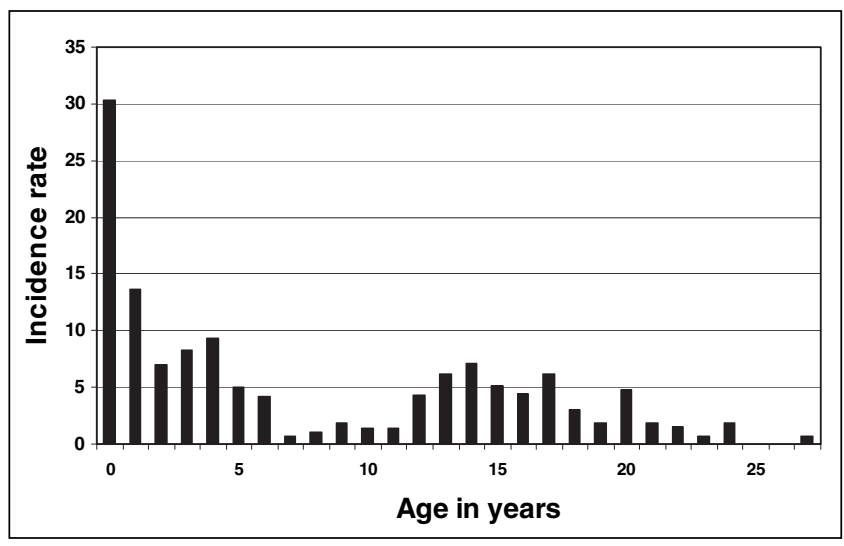

Figure 2) Incidence rate (per 100,000 per year) of invasive meningococcal disease in Quebec, according to age, from 1990 to 1992. Data from the Quebec Ministry of Health, written communication

\section{EFFICACY OF MENINGOCOCCAL VACCINES}

A quadrivalent $\mathrm{A}, \mathrm{C}, \mathrm{Y}$ and $\mathrm{W}-135$ polysaccharide vaccine has been available in Canada for many years. In young adults, short term protection against serogroups A and C IMD is around $90 \%$ (4). The duration of protection is not known. Following vaccination of military personnel in the United States, antigroups A and $\mathrm{C}$ bactericidal antibodies declined rapidly over the next two years but persisted above baseline for 10 years (19). There are no efficacy data for serogroups Y and W-135.

In Canada, a first serogroup $\mathrm{C}$ meningococcal conjugate vaccine was licensed in 2001 and several products are now available (4). Conjugate vaccines induce a T-cell dependent immune response implying a priming of immunologic memory, and immunity is thought to be long lasting. In the United Kingdom, the protection conferred by one dose of vaccine was around $90 \%$ in individuals aged one year or more (20), and three years after the initiation of a mass immunization campaign, there was no indication of waning immunity.

\section{COST EFFECTIVENESS OF IMMUNIZATION}

To evaluate the cost effectiveness of a publicly funded immunization program targeting young adults admitted to universities in Canada, a simulation model was constructed, derived from an epidemio-economic model evaluating alternative control strategies for children (21). The experience of a cohort of 100,000 students, $50 \%$ being vaccinated at the time of university admission, was analyzed and follow-up was 10 years. Input variables in the base model are presented in Table 1. IMD incidence rates were derived from Health Canada surveillance data in the age group 18 to 27 years, and for the period from 1995 to 1998 (Health Canada, written communication). In sensitivity analyses, the IMD incidence rate during a university stay of four years was multiplied by a factor of 0.5 (12) or 2.4 (13). Vaccine efficacy rates in the first year were based on US and UK data, and waning immunity rates over years were determined by experts, taking into account immunogenicity data (4). Incremental cost effectiveness and cost utility ratios from a societal perspective were calculated according to current guidelines (22).

Results are presented in Table 2 . The total cost of a program would be between $\$ 3$ and $\$ 4$ million, depending on the vaccine. The benefits in terms of overall IMD incidence reduction would 
TABLE 1

Values of input parameters in base model

\begin{tabular}{|c|c|c|}
\hline Input parameters & Value & Reference \\
\hline Number in cohort & 100,000 & \\
\hline Life expectancy at 18 years & 60.5 years & (28) \\
\hline Quality-adjusted life expectancy at 18 years & 50.1 years & (29) \\
\hline Lifetime earnings & $\$ 2,139,000^{*}$ & (30) \\
\hline IMD cumulative incidence age 18 to 21 years & 6.5 cases per $100,000^{\dagger \ddagger}$ & Health Canada, written communication \\
\hline IMD cumulative incidence age 22 to 27 years & 2.8 cases per $100,000^{\dagger}$ & Health Canada, written communication \\
\hline Proportion serogroup C & $55 \%^{\dagger}$ & Health Canada, written communication \\
\hline Proportion serogroups A, W-135 and $Y$ & $10 \%^{\dagger}$ & Health Canada, written communication \\
\hline Disease costs & $\$ 27,000$ per case & (31) \\
\hline Case fatality rate & $11 \%$ & (18) \\
\hline Sequelae rate in survivors & $20 \%$ & (18) \\
\hline Quality of life of survivors with sequelae & $72 \%$ & (32) \\
\hline Productivity of survivors with sequelae & $80 \%$ & (32) \\
\hline Polysaccharide vaccine efficacy first year & $90 \%$ & (33) \\
\hline Polysaccharide vaccine efficacy decrease & $10 \%$ per year & Expert opinion \\
\hline Polysaccharide vaccine purchase price & $\$ 35$ per dose $\$$ & Quebec Ministry of Health, written communication \\
\hline Conjugate vaccine efficacy first years & $90 \%$ & $(20)$ \\
\hline Conjugate vaccine efficacy decrease & $1 \%$ per year & Expert opinion \\
\hline Conjugate vaccine purchase price & $\$ 50$ per dose $\$$ & Quebec Ministry of Health, written communication \\
\hline Cost of adverse reactions & $\$ 0.03$ per dose & (31) \\
\hline Program coverage of target population & $50 \%$ & Expert opinion \\
\hline Vaccine administration cost & $\$ 24.59$ per dose $\pi$ & (34) \\
\hline Discounting rate & $3 \%$ per year & (35) \\
\hline
\end{tabular}

${ }^{*}$ Two times the lifetime average earning of Canadians; 'Invasive meningococcal disease (IMD) surveillance data for the period from 1995 to $1998 ;{ }^{\ddagger}$ Assuming half of cases occurring during first year; \$Purchase price for the public health system; TVaccine given alone in medical clinics

\section{TABLE 2}

Cost effectiveness of immunization against invasive meningococcal disease (IMD)

\begin{tabular}{llll}
\hline & Base model & Low incidence & High incidence \\
\hline $\begin{array}{l}\text { Quadrivalent polysaccharide vaccine } \\
\text { Program health service costs }\end{array}$ & $\$ 2,981,000$ & $\$ 2,981,000$ & $\$ 2,981,000$ \\
IMD cases averted & 2 & 1 & 4 \\
Societal cost per IMD case averted & $\$ 1,434,000$ & $\$ 2,751,000$ & $\$ 532,000$ \\
Societal cost per death averted & $\$ 13,040,000$ & $\$ 25,008,000$ & $\$ 4,834,000$ \\
Societal cost per life-year gained & $\$ 466,000$ & $\$ 893,000$ & $\$ 173,000$ \\
Societal cost per QALY gained & $\$ 364,000$ & $\$ 698,000$ & $\$ 135,000$ \\
Monovalent C conjugate vaccine & & & $\$ 3,731,000$ \\
Program health service costs & $\$ 3,731,000$ & $\$ 3,731,000$ & 4 \\
IMD cases averted & 2 & 1 & $\$ 2,695,000$ \\
Societal cost per IMD case averted & $\$ 1,619,000$ & $\$ 24,503,000$ & $\$ 695,000$ \\
Societal cost per death averted & $\$ 14,714,000$ & $\$ 875,000$ & $\$ 6,319,000$ \\
Societal cost per life-year gained & $\$ 525,000$ & $\$ 684,000$ & $\$ 226,000$ \\
Societal cost per QALY gained & $\$ 411,000$ & & $\$ 176,000$
\end{tabular}

QALY Quality-adjusted life-years

be small because only a maximum of four IMD cases would be prevented. A program relying on Men-C-Con would be more effective, but less cost effective, than a program using Men-4-PS. In all scenarios, economic indices exceeded proposed criteria for cost effective public health interventions $(23,24)$. For comparison, routine immunization of 12 -month old children with one dosage of monovalent conjugate vaccine would cost $\$ 190,000$ per IMD case prevented and $\$ 23,000$ per life year gained (21). IMD risk is higher in adolescents than in young adults (Figures 1 and 2), and routine immunization of pre-adolescents would also be more cost effective than a dose given at 18 years of age. Results of the economic analysis of vaccinating university students in Canada are concordant with analyses in the United States $(25,26)$. 
The perspective of the student should also be considered. The current sale price of Men-4-PS in a pharmacy is around $\$ 115$, and administration costs should be added. Receiving this vaccine in a clinic for travellers would cost around $\$ 155$. In a few Canadian universities and colleges, special clinics are organized on campus for administrating Men-4-PS at a cost of $\$ 90$ (Aventis Pasteur, written communication). For a university student, receiving Men-4-PS would decrease IMD risk over the next 10 years from one out of 11,000 to one out of 18,000 , a $41 \%$ reduction. In comparison, the sale price of Men-C-Con is $\$ 114$, and this vaccine would reduce IMD risk from one out of 11,000 to one out of 21,000 , a $48 \%$ reduction.

\section{CONCLUSION}

IMD is relatively rare in young Canadian adults, even during outbreaks, but the consequences of the disease can be dramatic. From a public health perspective, routine immunization of first year university students cannot be regarded as a priority. However, from the perspective of students and parents, the cost of vaccination might be worth the benefit in reducing IMD risk during university years. Presently, the best choice would be Men-C-Con administration before university admission. If serogroups $\mathrm{A}, \mathrm{Y}$ or $\mathrm{W}-135$ are becoming more prevalent, Men-4-PS could be recommended. A quadrivalent conjugate vaccine would certainly be the preferred option when available. Students who had previously received Men-4PS could benefit from an additional dose of Men-C-Con (27). Administration of meningococcal conjugate vaccine would certainly be more beneficial at a younger age (ie, during infancy or at 12 years of age), than at the beginning of university life.

\section{REFERENCES}

1. Harrison LH. Preventing meningococcal infection in college students. Clin Infect Dis 2000;30:648-51.

2. Kelleher JA, Raebel MA. Meningococcal vaccine use in college students. Ann Pharmacother 2002;36:1776-84.

3. Advisory Committee on Immunization Practices (ACIP). Meningococcal disease and college students. Recommendations. MMWR 2000;49:11-20.

4. National Advisory Committee on Immunization (NACI). Statement on recommended use of meningococcal vaccines. CCDR 2001;27:2-36.

5. Cartwright K. Meningococcal carriage and disease. In: Cartwright K, ed. Meningococcal Disease. Chichester: John Wiley \& Sons, 1995:115-46.

6. Neal KR, Nguyen-Van-Tam JS, Jeffrey N, et al. Changing carriage rate of Neisseria meningitidis among university students during the first week of term: Cross sectional study. BMJ 2000;320:846-9.

7. Jackson LA, Schuchat A, Reeves MW, Wenger JD. Serogroup C meningococcal outbreaks in the United States. An emerging threat. JAMA 1995;273:383-9.

8. Imrey PB, Jackson LA, Ludwinski PH, et al. Outbreak of serogroup $\mathrm{C}$ meningococcal disease associated with campus bar patronage. Am J Epidemiol 1996;143:624-30.

9. Gilmore A, Jones G, Barker M, Soltanpoor N, Stuart JM. Meningococcal disease at the University of Southampton: Outbreak investigation. Epidemiol Infect 1999;123:185-92.

10. Ferson M, Young L, Hansen G, et al. Unusual cluster of mild invasive serogroup $\mathrm{C}$ meningococcal infection in a university college. Commun Dis Intell 1999;23:261-4.

11. Round A, Evans MR, Salmon RL, et al. Public health management of an outbreak of group $\mathrm{C}$ meningococcal disease in university campus residents. Eur J Public Health 2001;11:431-6.

12. Neal KR, Nguyen-Van-Tam J, Monk P, O’Brien SJ, Stuart J,
Ramsay M. Invasive meningococcal disease among university undergraduates: Association with universities providing relatively large amounts of catered hall accommodation. Epidemiol Infect 1999;122:351-7.

13. Bruce MG, Rosenstein NE, Capparella JM, Shutt KA, Perkins BA, Collins M. Risk factors for meningococcal disease in college students. JAMA 2001;286:688-93.

14. Tyrrell GJ, Chui L, Johnson M, et al. Outbreak of Neisseria meningitidis, Edmonton, Alberta, Canada. Emerg Infect Dis 2002;8:519-21.

15. Bigham M, Trepanier MJ, Dobson S. Statistics and Reports: Meningococcal Disease in British Columbia. 2001 Summary. Vancouver: British Columbia Centre for Disease Control, 2002.

16. Bureau de surveillance épidémiologique (BSE). Épidémiologie des infections invasives à méningocoque, année 2001. Flash Méningo 2001;1:1-6.

17. Harrison LH, Dwyer DM, Maples CT, Billman L. Risk of meningococcal infection in college students. JAMA 1999;281:1906-10.

18. Erickson LJ, De Wals P, McMahon J, Heim S. Complications of meningococcal disease in college students. Clin Infect Dis 2001;33:737-9.

19. Zangwill KM, Stout RW, Carlone GM, et al. Duration of antibody response after meningococcal polysaccharide vaccination in US Air Force personnel. J Infect Dis 1994;169:847-52.

20. Balmer P, Borrow R, Miller E. Impact of meningococcal C conjugate vaccine in the UK. J Med Microbiol 2002;51:717-22.

21. De Wals P, Hung Nguyen V, Erickson LJ, Guay M, Drapeau J, St-Laurent J. Cost-effectiveness of immunization strategies for the control of serogroup C meningococcal disease. Vaccine. (In press)

22. Beutels P. Economic evaluation of vaccination programmes in humans. Universiteit Antwerpen, Faculteit Geneeskunde, Vakgroep Epidemiologie en sociale Geneeskunde, Antwerpen, Belgium: 2002.

23. Laupacis A, Feeny D, Detsky AS, Tugwell PX. How attractive does a new technology have to be to warrant adoption and utilization? Tentative guidelines for using clinical and economic evaluations. CMAJ 1992;146:473-81.

24. Laupacis A, Feeny D, Detsky AS, Tugwell PX. Tentative guidelines for using clinical and economic evaluations revisited. CMAJ 1993; 148:927-9.

25. Jackson LA, Schuchat A, Gorsky RD, Wenger JD. Should college students be vaccinated against meningococcal disease? A costbenefit analysis. Am J Public Health 1995;85:843-5.

26. Scott RD, Meltzer MI, Erickson LJ, De Wals P, Rosenstein NE. Vaccinating first-year college students living in dormitories for meningococcal disease. Am J Prev Med 2002;23:98-105.

27. Lakshman R, Burkinshaw R, Choo S, Finn A. Prior meningococcal $\mathrm{A} / \mathrm{C}$ polysaccharide vaccine does not reduce immune responses to conjugate vaccine in young adults. Vaccine 2002;3778-82.

28. Statistics Canada. Life tables, Canada and Provinces 1990-1992. Catalogue 84-537 Occasional. Ottawa: 1996.

29. Erickson P, Wilson RW, Shannon I. Years of healthy life. Statistical Note Number 7. Hyattsville: National Centre for Health Statistics, 1995.

30. Statistics Canada. Gains moyens selon le sexe et le regime de travail, 2000. <www.statcan.ca/francais/Pgdb/labor01a_f.htm> (Version current at February 6, 2004).

31. De Wals P, Erickson L. Economic analysis of the 1992-1993 mass immunization campaign against serogroup $\mathrm{C}$ meningococcal disease in Quebec. Vaccine 2002;20:2840-4.

32. Erickson L, De Wals P. Complications and sequelae of meningococcal disease in Quebec, Canada, 1990-1994. Clin Infect Dis 1998;26:1159-64.

33. Gold R, Artenstein MS. Meningococcal infections. 2. Field trial of group C meningococcal polysaccharide vaccine in 1969-70. Bull WHO 1971;45:279-82.

34. Centre for Infectious Disease Prevention and Control (CIDPC). Immunization Program Options for New Candidate Vaccines: Varicella, Conjugate Pneumococcal, Conjugate Meningococcal, Acellular Pertussis (TdaP). Ottawa: Health Canada, 2002.

35. Gold MR, Siegel JE, Russel LB, Weinstein MC. Cost-effectiveness in Health and Medicine. New York: Oxford University Press, 1996. 


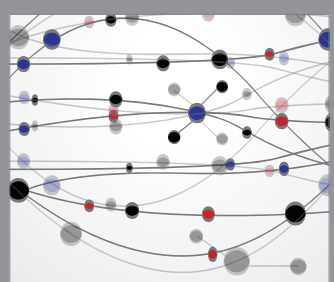

The Scientific World Journal
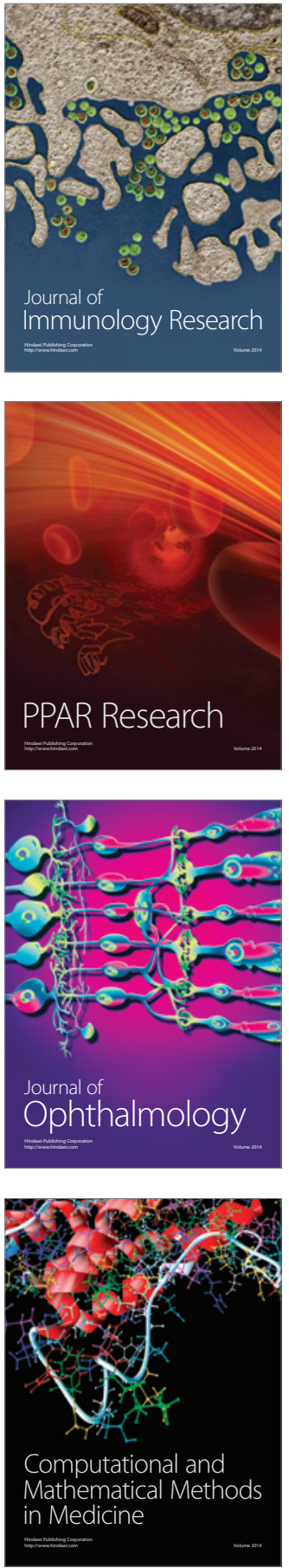

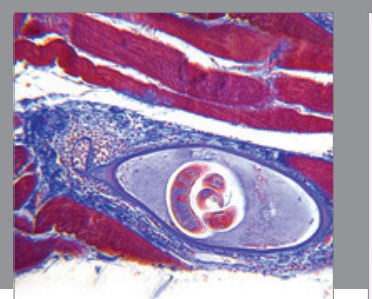

Gastroenterology Research and Practice

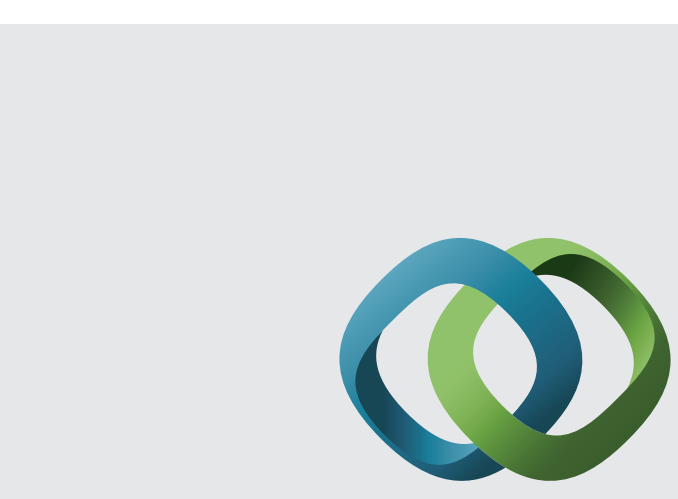

\section{Hindawi}

Submit your manuscripts at

http://www.hindawi.com
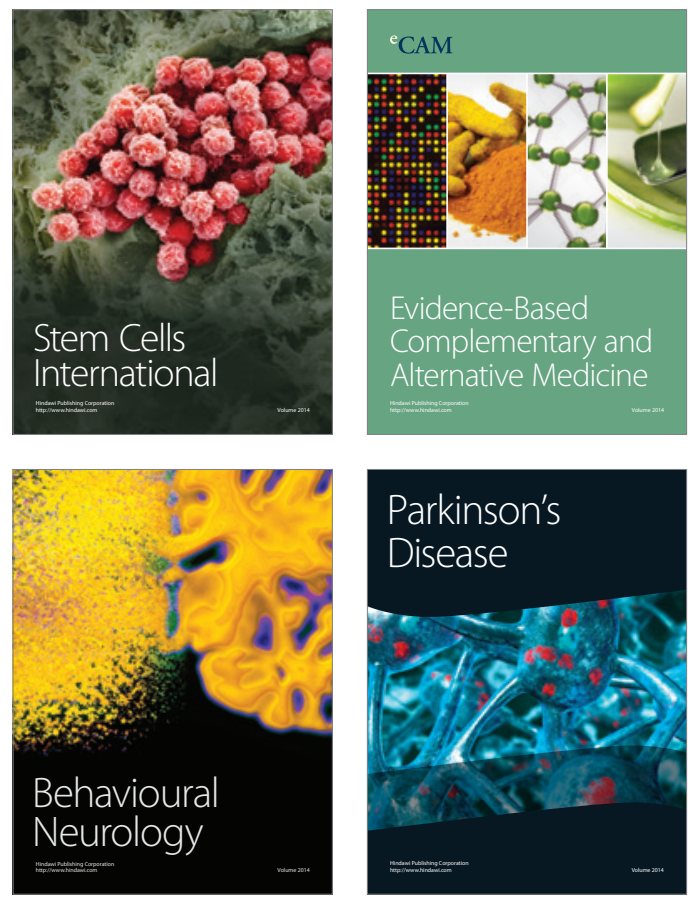
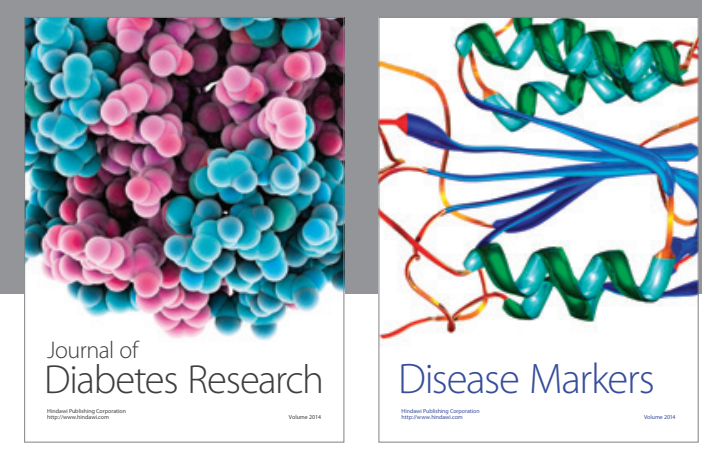

Disease Markers
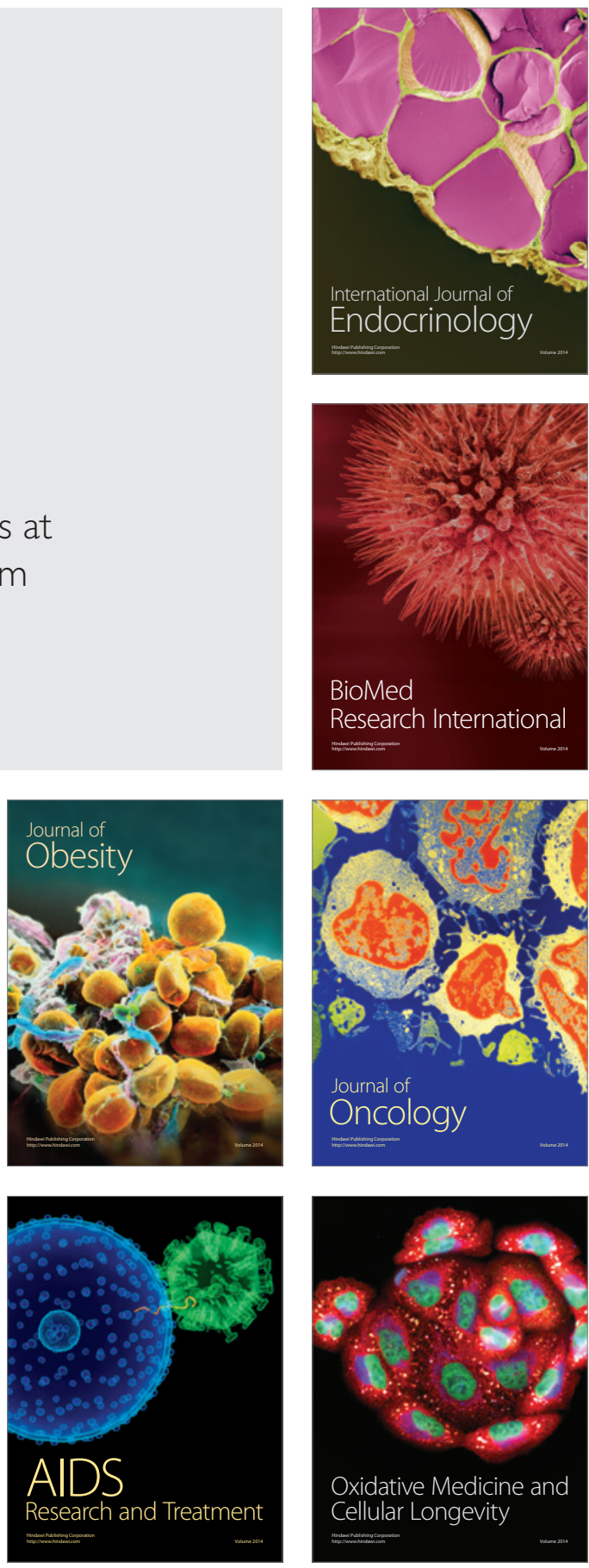